Paweł Żurawski

University of Lodz

Faculty of Economic and Sociology

Institute of Economics

e-mail: pawel.zurawski@edu.uni.lodz.pl

\title{
Lockdowns and their legitimacy in the context of Adam Smith's economic philosophy and liberalism
}

\begin{abstract}
Since the beginning of 2020, lockdowns have been introduced in numerous countries across the world in response to the emergence of coronavirus SARS-CoV-2 that causes the COVID-19 disease. Although the topic of lockdowns has been considered from numerous perspectives, it has not yet been analyzed in the context of Adam Smith's economic philosophy and liberalism. This paper aims to list - at least to some extent, as the topic is very broad - the most prominent arguments that have arisen in the worldwide discussion on the effectiveness and side effects of lockdowns. In addition, the work provides some elements of Smith's economic philosophy and liberalism. Finally, the arguments that have arisen in the academic discussion since the introduction of lockdowns are analyzed, and the legitimacy of lockdowns is assessed in the context of Smith's principles. The methods used for the analysis are text exegesis and rational reconstruction. As far as the conclusions are concerned, an explicit assessment of the legitimacy of lockdowns in the discussed context is considered impossible, although for many elements of Smith's liberalism, lockdowns are not legitimate at all.
\end{abstract}

Keywords: lockdown, Adam Smith, economic philosophy, liberalism, COVID-19

JEL Classification: B12, I15, P16 


\section{Introduction}

Lockdown as a policy introduced to reduce the pace of the spread of SARS-CoV-2 and the number of COVID-19 deaths has been used by numerous governments across the world since the emergence of the new coronavirus in winter 2019/2020. The policy has its supporters, who say that lockdowns are very efficient and saved millions of lives (Beaubien, 2020), and opponents, claiming that it is not only ineffective but also very harmful for the economy and the social life of individuals (Magness \& Earle, 2021). This paper approaches the arguments in the discussion on lockdowns from the perspective of the economic philosophy of the most famous economist and the Father of Classical Liberalism, Adam Smith, and assesses the legitimacy of lockdowns in the above context.

The topic of lockdowns, despite being analyzed from many angles, has not yet been discussed in the context of specific elements of Smith's economic philosophy, although it is very interesting and important as the majority of the scholar's ideas have been proved correct and useful since 1776, when "The Wealth of Nations" was published. The paper is divided into three sections, with the first two examining the main arguments in the current discussion on lockdowns and reconstructing the most relevant elements of Smith's economic philosophy. The last section is an analysis and the assessment of the above arguments in the context of his views.

Before embarking on discussing the arguments regarding lockdowns, however, it is noteworthy that some scholars argue that there is a worrying lack of pluralism as for the discussion itself. Caduf (2020) directly questions the widespread agreement for the necessity and justification of interventions aiming at flattening the curve of Sars-CoV-2 cases, while Loshe and Bschir $(2020$, p. 3) note that the process of making policy by governments is monopolized by people analyzing the problem from only one epistemic perspective and that "both forms of insufficient pluralism - external and internal to science - are problematic from an epistemological point of view." In his article, Bukowski (2020) even claims that a reasonable idea of not undermining the realities of the Sars-CoV-2 pandemic altered into the lack of the right to undermine the actions of governments. Therefore, Kilcoyne and Lesh (2020) raise the issue of economic expertise that should be included in policy-making in the UK. It might be due to the problem noticed by Caduf (2020), who raises the question of society- and economy-threatening government actions, which were taken with hardly any discussion regarding the costs they bear.

\section{The arguments in the discussion on lockdowns}

The costs of lockdowns are the first prominent argument in the lockdown discussion since taking into account only epidemiological aspects when making policy leads to neglecting social consequences (Lohse \& Bschir, 2020) or financial im- 
plications of any lockdown. Such policy mostly affects the young as, for instance, in the UK, 57\% of people aged between 35 and 44 , and $47 \%$ of people aged 18 to 34 and 45 to 54, noticed a negative impact of lockdown on their personal finances (compared to only $24 \%$ of the elderly, i.e., people older than 65). Moreover, lockdowns result in a standstill in the economy and an enormous decrease in economic growth (Kilcoyne \& Lesh, 2020). Additionally, the losses in trade are yet another cost of lockdown. In Spain, for instance, the decrease in trade, both in goods and services, was the greatest for decades, with a decline of almost $29 \%$ after lockdown. The situation in the trade in services is especially difficult due to the share of transport equipment and capital goods in the country's trade, as the demand for those decreased enormously and there was no tourism during lockdown (Minondo, 2021). Consequently, when locked down, economies and societies are in danger of collapse, as lockdowns create "poverty, hunger, misery, debt, and unemployment" (Caduf, 2020, p. 468).

The unemployment caused by labor and transportation bans, which is one of the key characteristics of lockdown, seems to be an important aspect that arises in the discussion in academia and the media. There are numerous instances of harmful lockdown side effects affecting the labor market around the world. According to Daniyal et al. (2020), a suddenly-imposed transportation ban in India left migrant workers stuck on their journey home from the cities where they worked during the first lockdown in the country. The lockdown also pushed daily wage workers in the country, counted in millions, into unemployment (Caduf, 2020). In New Zealand, only some businesses, such as pharmacies, supermarkets, and corner shops, were considered essential and could remain open, while others, for instance, bars or delivery services, were made by the government to close (Graham-McLay, 2020). In Poland, the lockdown had a negative influence on the labor market, with the most affected sectors of the economy being tourism, art, and culture (Radlińska, 2021), while closing stores in shopping malls for 114 days in 2020 led to the loss of revenues of almost 8 billion dollars by the industry. Additionally, more than 75,000 restaurants and bars were closed, which put as many as a million workplaces in danger (Podsumowanie lockdownu w Polsce, 2021).

The influence of the lockdown is even more problematic as a result of changing the initial idea to lock down the economy for two weeks to flatten the curve of SARS-CoV-2 cases to not overwhelm the health care system to a reoccurring phenomenon that depends on rates of cases and deaths. No number of cases that would clearly indicate the end of a lockdown and the reopening of previously closed businesses is announced in advance by the government, however, and the authorities seem to compete on how strict a particular lockdown is (Magness \& Earle, 2021).

The labor market restrictions are undoubtedly one of the reasons why the economies of many countries that introduced lockdowns shrank. According to Harari et al. (2021), as a consequence of the UK's first lockdown, its GDP decreased by $25 \%$ from February to April 2020. Although the economy visibly adapted to the restrictions (at the beginning of 2021, the fall in GDP was about 6\% compared to February 2020), every subsequent lockdown resulted in the economy 
shrinking. This is in accordance with the data from the Office for National Statistics, which stated that there was a GDP decline of $20 \%$ between the first and the second quarter of 2020 and a visibly smaller GDP decrease of $1.6 \%$ between the last quarter of 2020 and the first of 2021. Across the Atlantic Ocean, in the US, GDP "collapsed at a 32.9\% annualizd rate" in the second quarter of 2020. It was the greatest decrease since records began in 1947 (Mutikani, 2020). Only a slightly less disastrous real GDP decline of $31.2 \%$ compared to the proceeding period was reported in the second quarter of 2020 by the Bureau of Economic Analysis of the US Department of Commerce. Lockdown policies also negatively influenced the economies of Asian countries. For example, from April to June 2020, Japan recorded the most damaging quarterly decline after the Second World War, with the economy shrinking almost 5\% throughout lockdown-packed 2020 (Japan's economy shrinks $4.8 \%$ in 2020 due to Covid, 2021). The economic contraction in the countries that introduced lockdowns is not, however, the only harmful effect of such policy put forward in the discussion.

Many scholars raise the argument of the social effects of lockdowns, with people's mental health being the most discussed topic. The restrictions caused numerous new cases of mental health problems and limited the availability of support services. Those whose mental health worsened were mostly the people affected by the SARS-CoV-2 virus or the lockdowns introduced to fight it (The COVID decade..., 2021). However, this is contrary to the conclusion of the article by Ahrens et al. (2021), which states that a lockdown per se has no negative influence on mental health and it only impacts vulnerable groups of people, leaving others unaffected or even improving their condition due to less daily stress. Following this logic, one might question who belongs to the vulnerable group. According to Szredzińska and Włodarczyk (2021), children were particularly affected by lockdowns since they could not have had face-to-face contact with peers, for instance, at school, and were subject to movement restrictions. Additionally, uncertainty, anxiety, a lack of information, and domestic violence led children to depressed moods and other mental problems. Governments across the world neglect the above side effects and, as stated by Magness and Earle (2021, p. 511), "lockdowns, despite their clear socioeconomic harms and ambiguous or even dubious disease-mitigation benefits, remain a favored policy response to the ongoing pandemic."

What Magness and Earle (2021, p. 511) claim regarding "ambiguous or even dubious disease-mitigation benefits" is part of the discussion on the effectiveness of lockdowns as far as reducing the danger resulting from SARS-CoV-2 and COVID-19 is concerned. It is perhaps even the most important part of the discussion on lockdowns in general. This paper is not a medical one, so no explicit evidence-based statement regarding this matter will be given. Nevertheless, the discussion is ongoing and, therefore, various arguments will be described. Some are skeptical about the effectiveness of lockdowns, stating that they ruin livelihoods and do not reduce the pace of the spread of the virus at all (The Economist, 2021). Kowalewski (2020) provides the instance of Latin America, where many countries introduced extremely severe lockdowns. Although they did not reduce the increase 
in the number of SARS-CoV-2 cases, they did weaken some economies. One reason for this is the well-developed grey market in many of the countries, where individuals barely care about state-imposed restrictions.

By contrast, according to Grigoli and Sandri (2020), despite the short-term negative consequences, lockdowns do reduce the number of SARS-CoV-2 cases and, thus, might even accelerate the economic recovery process. This opinion is shared by the Prime Minister of New Zealand, Jacinda Ardern, who introduced very tight restrictions, including obligatory quarantine of the whole nation, arguing that such a policy decreases the number of SARS-CoV-2 cases and shortens the period of crisis and the shrinking of the economy (Karnon, 2020). In addition, according to the World Health Organization (Coronavirus disease (COVID-19)..., 2020), lockdowns may reduce the speed of transmission of the disease due to people having less contact with each other. However, the WHO notes that lockdowns can negatively influence the economic or social lives of individuals and whole societies, mostly the poor, migrants, or refugees.

Kelland (2020) states that, according to studies by Imperial College London, the infection's reproductive rate, which is a value measuring "the average number of people that one infected person will pass the disease on to," was decreased by lockdowns. However, as Caduf (2020) stated, no-one knows if the lockdown in China had a positive impact on decreasing the spread of the virus or if there was virus burn-out and it simply did not move to other parts of the country. Additionally, there are many countries in which very strict lockdowns were introduced, and their mortality rates per capita were exceptionally high, which would suggest that such policies are only a reaction to the increase of the rates and are not a powerful enough measure to stop it. Ultimately, there is no clear connection between lockdowns and a decrease in the COVID-19 mortality rate (Magness \& Earle, 2021). The above statements and opinions regarding the effectiveness of lockdowns in slowing down the spread of the virus and its economic and social side effects make the current debate on the topic in academia and the media seem endless.

\section{The principles of Smith's economic philosophy and liberalism}

Adam Smith, who is commonly known as "The Father of Economics" (Brown, 1997) and "The Father of Capitalism" (Adam Smith..., 2017), discussed in his two most famous works, "The Theory of Moral Sentiments" and "The Wealth of Nations", many issues related to the economy of a state and individual actors in the economy. His philosophical views were based on rationalism, from which comes one of the rules of Smith's philosophical approach - individualism. According to Chodorowski (2002), Smith states that what differentiates a human being from an animal is the ability and inclination to barter. Animals cannot exchange things, and humans' natural tendency to do it results from capacities of reason, which are natural for people (Otteson, 2013). Moreover, bartering, i.e., a form of transaction 
on the market, creates social bonds, and the benefits from it are what people seek in social interactions (Lisak, 2016).

What is interesting is that in social interactions and when bartering, people seem to act rationally. According to Lisak (2016), Smith claims this rationality is due to a phenomenon that he discovered himself - the invisible hand of the market. When interacting, individual economic actors who participate in the market and are autonomous create a sort of order. Such order arises spontaneously, without central planning, as a result of each individual following his own interests, and it is beyond the imagination of each market participant (Lisak, 2016). In other words, every person, using their knowledge, tries to put oneself in the most fortunate circumstances, at the same time, inadvertently, improving others' situations (Otteson, 2013). In "The Wealth of Nations", Smith admires the astonishing results of the phenomenon he discovered, underlying its free-of-planning nature (Boudreaux, 2020). He explains many times that general welfare is unintentionally improved by individuals who are willing to achieve their personal objectives. However, this happens in a system that is based on economic freedom (Godłów-Legiędź, 2001).

Such a system is even described by the author in "The Wealth of Nations" as "the obvious and simple system of natural liberty" (Smith, 1776/1976, p. 687). In such an economy, based on a free market, things happen naturally. There is freedom of competition. The sellers sell as expensively as possible, and the buyers strive to buy as cheaply as possible. The economy self-regulates thanks to both free market and competition, which allocate labor and capital most effectively. Consequently, there is an increase in the national wealth. In such a naturallydriven economy of perfect liberty, an individual economic actor, apart from acting rationally, analyzing one's own interests and, when unintentionally improving public good striving to achieve personal objectives (the invisible hand of the free market), can freely make economic decisions, including those related to choosing and changing one's profession (Zabieglik, 2006). It is noteworthy, however, that, as stated by Godłów-Legiędź (2001), Smith in "The Wealth of Nations" presents a society whose functioning is based on freedom, private property, and competition (a model of a free-market economy). However, he also notices that in some cases, free competition is not possible, even though he admires the outstanding results to which it leads in all areas.

Taking into account the mechanism of self-regulation based on the free market and competition, it seems obvious that Smith was a proponent of the limited role of the state in the economy. As reported by Boudreaux (2020), throughout "The Wealth of Nations", he argues that an average person is capable of taking care of one's own interests well unless one is loaded with duties and limits imposed by a government, which, in Smith's eyes, aim to increase the wealth and conditions of the elites at the cost of the situation of the masses. This capability seems to be of great importance for Smith since he sees it as the basis for a righteous life. Being able to control oneself and govern one's own life is the key to self-discipline, which makes it possible to be generous or humane, among others. Without this capability, virtues lack their principal luster (Otteson, 2013). Never- 
theless, obviously, since Smith was no anarcho-capitalist, the ability to self-govern does not mean that individuals ought to be governed by nothing but themselves. Nonetheless, it should be free competition and common law jurisdiction rather than legislative or bureaucratic commands and directives that govern free individuals (Boudreaux, 2020). Thus, regarding the role of the state, Smith says (1776/1976, pp. 687-688),

the sovereign has only three duties to attend to (...): first the duty of protecting the society from the violence and invasion of other independent societies; secondly, the duty of protecting, as far as possible, every member of society from the injustice or oppression of every other member of it, or the duty of establishing an exact administration of justice; and, thirdly, the duty of erecting and maintaining certain public works and certain public institutions, which it can never be for the interest of any individual, or small number of individuals, to erect and maintain; because the profit could never repay the expense to any individual or small number of individuals, though it may frequently do much more than repay it to a great society.

Additionally, according to Godłów-Legiędź (2001), he believes that there is one more role of the government - to educate common people. Lipford and Slice (2007) recognize, however, that Smith states that such education can be cheap and does not have to cover knowledge at an extended level as the common people should be taught to read, write and count.

Although the role of the state should be limited to defending the nation, which should be provided with some minor public goods (both done at the most local level possible) (Boudreaux, 2020), the existence of public good is not neglected by Adam Smith. According to Lisak (2016), however, the idea of public good has its limits in Smith's works. It is mostly related to economic matters and, eventually, it is to lead to economic growth. Nevertheless, according to Nawaleniec (2016), Smith claims that when making a decision, the authorities should not be governed by the protests of bothersome individuals who strive to achieve their own objectives, but the public good. This is in accordance with the statement of Zabieglik (2006), who notes that, according to Smith, if a private interest and the public good are two contrary things, the latter should be treated as more important. Although he notices the same limits to the concept as Lisak does, he states that for Smith, anything that is required by the national defense is included in the public good as well. Therefore, economic freedom can be suspended, and certain restrictions and prohibitions can be introduced if the nation must be defended since prosperity is less important than defending the nation. Yet, as noticed by Boudreaux (2020), Smith does not become blinded to the fact that the matter of national security is and will be used by politicians and experts in the future to justify, for instance, trade restrictions and that they will voice concern about the national security even if it is not really in danger. As stated by Zabieglik (2006), he even gives an instance of such restriction when discussing the labor ban imposed on British craftsmen, stating that it is against the freedom of the craftsmen and that their freedom was being sacrificed for the narrow-minded interests of merchants and manufacturers. Zabieglik (2006, p. 121) summarizes the problem stating that for Smith: 
the freedom of making economic choices means, in particular, that contract workers can change work at any time. "The perfect freedom" has its limits, however. The state may forbid a few, but not many individuals from exercising natural freedom if their actions endanger the security of the whole of society. Such restrictions may also apply to business activities.

Taking the above paragraph into consideration, it is safe to say that Godłów-Legiędź (2001) is correct when stating that Smith does not believe in the perfect harmony of the interests of individuals and the public good.

In addition to emphasizing the limited role of the state in the economy, Smith seems to warn society against the incompetent decisions and its wide-ranging actions of government, and he warns the government itself against believing in its ability and competence to command individuals' lives. As reported by Otteson (2013), in "The Wealth of Nations", he repeats many times the danger of overestimating one's ability to know what is best for another person, judging a particular situation instead of leaving the judgment to the other, sometimes even compulsorily, and the willingness to impose penalties on those who are not able or do not want to be part of the government's plan. Furthermore, Smith states that eventually, the government can abandon the plan or introduce it using force since people naturally think for themselves and do not follow patterns, disordering the plan in many ways that cannot be predicted. The arrogance and stupidity of a person who thinks that one is able to command others' lives is summarized in the following quotation from Smith's “The Wealth of Nations" (1776/1976, p. 456):

What is the species of domestic industry which his capital can employ, and of which the produce is likely to be of the greatest value, every individual, it is evident, can, in his local situation, judge much better than any statesman or lawgiver can do for him. The statesman who should attempt to direct private people in what manner they ought to employ their capitals would not only load himself with a most unnecessary attention, but assume an authority which could safely be trusted, not only to no single person, but to no council or senate whatever, and which would nowhere be so dangerous as in the hands of a man who had folly and presumption enough to fancy himself fit to exercise it.

Otteson (2013) summarizes this, claiming that, according to Smith, the scope of the authority of the government regarding the decisions made by individuals on the best possible employment of their capitals should be limited. Additionally, he notes Smith's criticism of whom the author of "The Wealth of Nations" called "man of system". Adam Smith (1759/1989, pp. 348-349) criticizes such "man of system", stating the following:

He seems to imagine that he can arrange the different members of a great society with as much ease as the hand arranges the different pieces upon a chess-board. He does not consider that the pieces upon the chess-board have no other principle of motion besides that which the hand impresses upon them; but that, in the great chess-board of human society, every single piece has a principle of motion of its own, altogether different from that which the legislature might chuse to impress 
upon it. If those two principles coincide and act in the same direction, the game of human society will go on easily and harmoniously, and is very likely to be happy and successful. If they are opposite or different, the game will go on miserably, and the society must be at all times in the highest degree of disorder.

Therefore, it comes as no surprise that Smith thinks, as stated by Zabieglik (2006), that a state becomes poorer due to the waste of public money and bad governing, not the prodigality or bad self-command of individuals. It results from the fact that, as Otteson noted (2013), he considers the constant striving of each individual to achieve one's objectives enough to lead to an improvement in the natural way despite the government's extravagance and huge mistakes of administration.

\section{The legitimacy of lockdowns in the context of Smith's economic philosophy and liberalism}

First and foremost, the broadly discussed negative economic implications of a lockdown, such as the decline in GDP in the countries that introduced the policy, are what could undermine the legitimacy of the decisions that lead to locking down the economy in the context of Smith's liberalism. As noticed by Zabieglik (2006) above, Smith argues that the poverty of a country is frequently caused by the waste of public money and bad governing. Lockdowns obviously make the countries in which they occur grow poorer, as the examples of the UK, the US, and Japan given in the second section show. From the economic perspective only, decisions that make GDP fall drastically might, therefore, be called bad governance. Additionally, regarding the waste of public money, one should note that the fight against SARS-CoV-2 is very expensive in the countries where lockdowns have been imposed so far. In the UK, the government borrowed the greatest amount of money ever recorded, almost 300 billion pounds, from April 2020 to 2021 as, due to the lockdown, the amount of money raised in taxes decreased dramatically (King, 2021). In the US, the budget deficit reached 1.7 trillion dollars in March 2021, as the federal government had to pump money into the economy that was weakened by lockdown (Nelson, 2021). In Poland, in 2020, the public debt per capita reached almost 35,000 zlotys, with the overall debt being over 1.3 trillion zlotys (Unton, 2021). Taking into account what Smith pinpoints as poverty-creating elements, lockdowns seem by no means legitimate.

While bad governance and the waste of public money were what Smith considered reasons for countries becoming poor, one should also remember what, according to the Scottish economist, the wealth-making phenomenon is. To a huge extent, "the invisible hand," alongside the conditions in which it leads to the improvement of the wealth of a nation (free market and competition), were rolled out from the economy in countries that introduced lockdown. The imposition of a centrally-planned lockdown that restricted individuals' actions to keep them 
healthy can by no means be seen as being in accordance with Smith's belief in the rationality of people, for which "the invisible hand" is the basis, which leads to a spontaneously developing order. If a decision to announce a lockdown is made, it means that the one making it does not believe that an individual can act to improve his or her condition, simultaneously improving the situation of others, and must be obligated to act in a particular way. Furthermore, Smith's "obvious and simple system of natural liberty" (1776/1976, p. 687) cannot coexist with a locked-down economy as two out of the three basic elements of Smith's functioning society, i.e., freedom and competition, are limited, and the third one, private property, is endangered since in many locked down countries, for instance in Poland, entrepreneurs lose their businesses and property due to lockdowns (Kowalska, 2021). Finally, it is doubtful whether, during a lockdown, one is able to choose or change one's profession, which is another previously discussed element of Smith's economic philosophy noted by Zabieglik (2006). Ergo, taking into consideration the phenomenon of the invisible hand, the free market, and competition, it is safe to state that in the context of those principles of Smith's economic philosophy, a lockdown is not an allowable policy.

As for the argument regarding the social effects of lockdowns, such as the worsening of the mental health of people affected by the policy or the virus itself (The COVID decade..., 2021), one particular element of Smith's philosophy not yet discussed in the paper should be emphasized. According to Otteson (2013), he considers tranquility to be the core of happiness, and in this matter, his ideas are close to the stoic approach. For Smith (1989, p. 215), happiness "consists in tranquility and enjoyment. Without tranquility there can be no enjoyment; and where there is perfect tranquility there is scarce anything which is not capable of amusing." It is obvious that tranquility and enjoyment cannot be found during lockdowns, a time of uncertainty, which might be the reason for many cases of depression among children, as found by Szredzińska and Włodarczyk (2021) quoted above. Moreover, according to Smith, the characteristic that distinguishes us from animals, i.e., the ability and tendency to barter, is also responsible for creating social bonds (Lisak, 2016), which were significantly affected by lockdowns (Vrain et al., 2020). Summarizing, lockdowns affect tranquility and enjoyment, the major parts of happiness, according to Smith, as well as the social bonds created via bartering. Taking it into account, it should be stated that the argument of the negative social effects of lockdowns in the context of Smith's liberalism is yet further proof of the unjust nature of lockdowns. This would be entirely true if it were not for the doubts regarding the negative effects expressed by, for instance, Ahrens et al. (2021) cited above. Thus, an unambiguous evaluation of the legitimacy of lockdowns in the context of Smith's economic philosophy in this case cannot be made.

The same problem of the ambiguity of the assessment arises on the subject of lockdowns with regard to Smith's idea of the role of the state in the economy and the public good. At first sight, in the context of those elements of Smith's economic philosophy, no lockdown is legitimate since he finds three, or a maximum of four duties of the state, including the protection of society from any external ene- 
my; protecting every individual in society from an internal enemy who is another individual in society, in addition to establishing an honest and well-organized judicial system; providing public goods, mostly infrastructure, i.e., roads, bridges or harbors; and finally providing very basic education for the average person so they could read, write, and count (Lipford \& Slice, 2007), but excluding the creation and running of a healthcare system. Moreover, as noted by Boudreaux (2020) above, Smith believes that an individual can support oneself if the government does not impose on the individual too many duties and limits whose objective is to improve the condition of the rich at the expense of the poor. Such an introduction of duties and limits is exactly what happens when a lockdown is imposed in any country. Finally, Smith rejects the idea that legislative decrees, such as ministerial orders, can be what governs free individuals (Boudreaux 2020). Thus, in the context of the principle of Smith's liberalism regarding the limited role of the state in the economy, lockdowns are not legitimate.

Nevertheless, what creates ambiguity in the assessment is the concept of the public good in Smith's works. As reported by Lisak (2016), the public good is related to a country's economy and is quite similar to the idea of economic growth. In such a context, lockdowns seem even less legitimate as they lead to a decline in economic growth. Yet, as noted by Zabieglik (2006), Smith recognizes the superiority of the public good over the individual's interests and sees the defense of the nation as a part of a public good. Against such a background, the restrictions and prohibitions of lockdowns are legitimate as long as the nation must be defended. Nonetheless, there is a question of whether a nation must be defended by a state using lockdown against SARS-CoV-2 and COVID-19 since the effectiveness of lockdowns, as the second section of the paper shows, is still a subject to discussion in academia and the media. According to Magness and Earle (2021), Kowalewski (2020), and Caduf (2020), lockdowns do not slow down the spread of the virus and do not reduce the mortality rate of COVID-19.

However, as reported by Kelland (2020) and stated by the WHO (2020) and Grigoli and Sandri (2020), lockdowns do reduce the number of SARS-CoV-2 cases. In line with Graham-McLay (2020), one might also question the seriousness of the danger when a lockdown is introduced. For instance, in New Zealand, a very severe lockdown was introduced when there were 205 confirmed or even just probable cases, and no deaths. It is notable for the assessment of the legitimacy of lockdowns in the context of Smith's liberalism as he is aware that the notion of the public good, national security, or the national health, in this case, could be used to impose restrictions in the situation of a doubtful danger. Additionally, Smith criticizes labor prohibitions, considering them a violation of workers' freedom, and unemployment-creating labor prohibitions are one of the arguments against lockdown discussed above. Finally, Smith was a staunch critic of contradictory restrictions on trade imposed by the government (Buchholz, 1989). In many countries, including Poland, the decision to introduce lockdowns seemed to be far from rational or reasonable, taking into account that the most severe lockdown was introduced when there were, according to Medicover (2021), 51 SARSCoV-2 cases and 1 COVID-19 death confirmed and was almost totally ended 
when there were 42038 cases and 1655 confirmed deaths (Podsumowanie lockdownu w Polsce, 2021). When analyzing the legitimacy of lockdowns in the context of Smith's economic philosophy regarding the concept of public good, the analysis is complex, and the assessment cannot be other than ambiguous.

Finally, there is one more element of Smith's economic philosophy in the context of which the legitimacy of lockdowns will be discussed. Throughout his works, he warns societies against people who seek power over others, so-called "men of system," and claims that merely seeking such power means that one cannot be entrusted with it (Smith, 1776/1976, p. 456; cf. Boudreaux 2020). As pinpointed by Otteson (2013), Smith considers overestimating one's ability to assess what is good for others and taking away the possibility of judgment to be dangerous and warns against authorities who are willing to punish individuals who do not follow their idealistic plan. Smith's confidence that a government would eventually have to use power against disobedient citizens or abandon the plan seems to be proved in countries where lockdowns are introduced. Instances of the use of power while introducing lockdowns are countless, from relatively soft ones, such as fining people 10,000 zlotys in Poland for riding a bike or running in the park (Kośka, 2021), to cruel and vicious ones, such as beating and tear-gassing Kenyans returning home from work and forcing them to lie down for hours on one another for alleged curfew violations (Namwaya, 2020). These examples seem to prove what Smith states about people who want to centrally control the social system - they do not understand the nature of social phenomena. Taking examples of the use of power when introducing lockdowns across the world, it is safe to state that Otteson (2013, p. 102) is right when he says that

Smith's argument thus presents a serious challenge to contemporary political philosophy, much of which contains careful delineations of the decisions that third parties are presumed competent to make and the areas of human life government is presumed competent to superintend.

Therefore, in the context of this last element of Smith's economic philosophy, i.e., the criticism of a "man of system" and his actions to control individuals" lives, lockdowns are not legitimate at all.

\section{Conclusions}

To conclude the analysis of the legitimacy of lockdowns in the context of Adam Smith's economic philosophy and liberalism, it must be stated that the assessment of the policy, although at first sight it might seem obvious and explicit, is ambiguous and complex in the case of some concepts he discussed. Regarding the economic effects of lockdowns, i.e., mostly unemployment, trade restrictions, and labor restrictions that lead to the shrinking of the economy, lockdowns seem by no means legitimate in the context of his views. Additionally, for the free market, free competition, and "the invisible hand," Smith's ideas seem quite straightforward as 
well, leaving the unjust nature of a lockdown unquestionable as such a policy practically leads to destroying free competition and the free market, and it limits the ability of free individuals to self-command; so, if it does not cut off "the invisible hand" it shortens it.

Smith also claims that the role of the state in the economy should be limited to defending citizens against external and internal enemies, providing an honest judicial system and public goods, such as infrastructure, and educating people at a very basic level. Thus, in this context, lockdowns are needless instances of state interventionism. Finally, Smith warns society against "men of system," i.e., authorities who strive to control free human beings. Lockdowns obviously limit people's freedoms and, therefore, from the perspective of Smith's concept of "man of system," are not justified. Nevertheless, in the matter of the negative social effects of lockdowns, i.e., mostly worsening mental health of individuals, the assessment of the policy is more complex. It is mostly due to the fact that, although there are many articles stating that the negative effect is obvious, some scholars argue that lockdowns only affect small groups of the most vulnerable people.

The true source of the ambiguity of the assessment of the legitimacy of lockdowns is, however, the lack of consensus regarding the effectiveness of such a policy. Some scholars argue that lockdowns neither reduce the pace of the spread of the virus nor decrease the number of deaths. Or even, like the Nobel prize-winning professor Michael Levitt, they claim that lockdowns could increase the number of overall deaths in a country (Scarlett, 2020). However, others state that they save lives by reducing the contact between people, which, in turn, results in a decrease in the number of SARS-CoV-2 cases and COVID-19 deaths. It seems to be the key issue in the context of how Smith describes the idea of the public good. If the danger was real, i.e., national security or public health were really endangered, and lockdowns were undoubtedly effective, then even in the context of Smith's economic philosophy, they could be seen as legitimate, since Smith considers the public good to be more important than individuals' interests, and he permits labor or trade restrictions in very specific situations. Nonetheless, the discussion on the effectiveness of lockdowns is ongoing, and with the current knowledge, lockdowns cannot be considered either legitimate or not legitimate in the context of Adam Smith's economic philosophy and liberalism, despite the fact that for many particular elements of the philosophy, they undoubtedly lack legitimacy.

\section{References}

Adam Smith: Father of Capitalism [Audio podcast episode]. (2017). In The Forum. BBC World Service, November 18. https://www.bbc.co.uk/sounds/ play/w3csvsfb 
Ahrens, K. F., Neumann, R. J., Kollmann, B., Plichta, M. M., Lieb, K., Tüscher, O. \& Reif, A. (2021). Differential impact of COVID-related lockdown on mental health. World Psychiatry, 20(1), 140-141. https://doi.org/10.1002 /wps. 20830

Beaubien, J. (2020). Modelers Suggest Pandemic Lockdowns Saved Millions From Dying Of COVID-19. npr, June 9. https://www.npr.org/sections/goatsandso da/2020/06/09/872441984/modelers-suggest-pandemic-lockdowns-saved-mi llions-from-dying-of-covid-19? $\mathrm{t}=1628519246010$

Boudreaux, D. J. (2020). Today's Relevance of Adam Smith's Wealth of Nations. The Independent Review. Journal of Political Economy, 24(4), 487-497.

Brown, V. (1997). 'Mere Inventions of the Imagination': A Survey of Recent Literature on Adam Smith. Economics \& Philosophy, 13(2), 281-312. https://doi.org/10.1017/S0266267100004521

Buchholz, T. G. (1989). New Ideas from Dead Economists: An Introduction to Modern Economic Thought. New York: The Penguin Group.

Bukowski, W. (2020). La Viralità del Decoro. Controllo e Autocontrollo Sociale ai Tempi del Covid-19. Seconda puntata. https://www.wumingfoundation. com/giap/2020/03/la-viralita-del-decoro-2/

Bureau of Economic Analysis. (2021). Percent Change From Preceding Period in Real Gross Domestic Product. https://apps.bea.gov/iTable/iTable.cfm?re qid=19\&step=2\#reqid=19\&step=2\&isuri=1\&1921=survey

Caduf, C. (2020). What went wrong: Corona and the world after the full stop. Medical Anthropology Quarterly, 34(4), 467-487. https://doi.org/10.1111/ maq.12599

Chodorowski, J. (2002). Adam Smith (1723-1790). Życie i dzieło autora „Badań nad natura i przyczynami bogactwa narodów”. Wrocław: Wydawnictwa Uniwersytetu Wrocławskiego.

Coronavirus disease (COVID-19): Herd immunity, lockdowns and COVID-19. (2020). WHO. https://www.who.int/news-room/q-a-detail/herd-immunitylockdowns-and-covid-19

Daniyal, S., Sharma, S. \& Fernandes, N. (2020). As Covid-19 Pandemic Hits India's Daily-wage Earners Hard, Some Leave City for Their Home Towns. Scroll.in, March 21. https://scroll.in/article/956779/starvation-will-kill-us-be fore-corona-the-covid-19-pandemic-has-hit-indias-working-class-hard

Godłów-Legiędź, J. (2001). Liberalizm Od ekonomii klasycznej do polityki transformacji. Łódź: Przedsiębiorstwo Specjalistyczne "Absolwent".

Graham-McLay, C. (2020). Ardern urges New Zealanders to 'act like you have Covid-19' as lockdown looms. The Guardian, March 25. https://www.the guardian.com/world/2020/mar/25/ardern-urges-new-zealanders-to-act-likeyou-have-covid-19-as-lockdown-looms 
Grigoli, F. \& Sandri, D. (2020). COVID's Impact in Real Time: Finding Balance Amid the Crisis. International Monetary Fund, October 8. https://blogs.imf. org/2020/10/08/covids-impact-in-real-time-finding-balance-amid-the-crisis/

Gross Domestic Product: chained volume measures: Seasonally adjusted $£$ m. (2021). Office for National Statistics. https:/www.ons.gov.uk/economy/ grossdomesticproductgdp/timeseries/abmi/pn2

Harari, D., Keep, M. \& Brien, P. (2021). Coronavirus: Economic impact. https:// commonslibrary.parliament.uk/research-briefings/cbp-8866/

How to assess the costs and benefits of lockdowns. (2021). The Economist, July 3. https://www.economist.com/finance-and-economics/2021/07/01/how-toassess-the-costs-and-benefits-of-lockdowns

Japan's economy shrinks 4.8\% in 2020 due to Covid. (2021). BBC News, February 15. https://www.bbc.com/news/business-56066065

Karnon, J. (2020). A Simple Decision Analysis of a Mandatory Lockdown Response to the COVID-19 Pandemic. Applied Health Economics and Health Policy volume, 18, 329-331. https://doi.org/10.1007/s40258-020-00581-w

Kelland, K. (2020). Lockdowns saved many lives and easing them is risky, say scientists. Reuters, June 8. https://www.reuters.com/article/us-health-coro navirus-lockdowns-idUSKBN23F1G3

Kilcoyne, M. \& Lesh, M. (2020). Young hit hardest by lockdown, want tax cuts A survey of the U.K. population. Adam Smith Institute.

King, B. (2021). How much is Covid costing the UK and how will we pay? BBC News, June 22. https://www.bbc.com/news/business-52663523

Kośka, M. (2021). Zakaz przemieszczania się niezgodny z prawem. SN wypunktowat błędy rządu. Money.pl, 17 marca. https://www.money.pl/gospodarka/zakazprzemieszczania-sie-niezgodny-z-prawem-sn-wypunktowal-bledy-rzadu-661 8980307548768a.html

Kowalewski, P. (2020). Pandemia pustoszy Amerykę Łacińska. Obserwator Finansowy, 3 listopada. https://www.obserwatorfinansowy.pl/tematyka/makro ekonomia/trendy-gospodarcze/pandemia-pustoszy-ameryke-lacinska/

Kowalska, D. (2021). Lockdown zmora przedsiębiorców. Traca na nim dorobek życia. Polska Times, 8 kwietnia. https://polskatimes.pl/lockdown-zmoraprzedsiebiorcow-traca-na-nim-dorobek-zycia/ar/c15-15533699

Lipford, J. W. \& Slice, J. (2007). Adam Smith's Roles for Government and Contemporary U.S. Government Roles. Is the Welfare State Crowding Out Government's Basic Functions? The Independent Review. A Journal of Political Economy, 11(3), 485-501.

Lisak, A. (2016). Kilka tez o racjonalności w ekonomii. In: P. Dominiak and P. Parszutowicz (Eds.), Adam Smith w 240. rocznice wydania „Bogactwa Narodów” (pp. 63-90). Warszawa: Wydawnictwo Instytutu Filozofii i Socjologii PAN. 
Lohse, S. \& Bschir, K. (2020). The COVID-19 pandemic: A case for epistemic pluralism in public health policy. History and Philosophy of the Life Sciences, 42(4), article no. 58. https://doi.org/10.1007/s40656-020-00353-8

Magness, P. W. \& Earle, P. C. (2021). The Origins and Political Persistence of COVID-19 Lockdowns. The Independent Review. A Journal of Political Economy, 25(4), 503-520.

Minondo, A. (2021). Impact of COVID-19 on the trade of goods and services in Spain. Applied Economic Analysis, 29(85), 58-76. https://doi.org/10.1108/ AEA-11-2020-0156

Mutikani, L. (2020). What to know about the report on America's COVID-hit GDP. World Economic Forum, July 31. https:/www.weforum.org/agenda/ 2020/07/covid-19-coronavirus-usa-united-states-econamy-gdp-decline/

Namwaya, O. (2020). Kenya Police Abuses Could Undermine Coronavirus Fight. Authorities Should Investigate Claims of Excessive Force, Abuse. Human Rights Watch, March 31. https://www.hrw.org/news/2020/03/31/kenyapolice-abuses-could-undermine-coronavirus-fight

Nawaleniec, A. (2016). Etyczne aspekty życia gospodarczego w okresie od starożytności do końca XIX wieku. https://www.profesor.pl/publikacja,31725,Artyku ly,ETYCZNE-ASPEKTY-ZYCIA-GOSPODARCZEGO-W-OKRESIE-OD -STAROZYTNOSCI-DO-KONCA-XIX-WIEKU

Nelson, E. (2021). Pandemic Spending Pushes U.S. Budget Deficit to \$1.7 Trillion. The New York Times, April 12. https:/www.nytimes.com/live/2021/ 04/12/business/stock-market-today

Otteson, J. R. (2013). Adam Smith. London: Bloomsbury.

Podsumowanie lockdownu w Polsce. (2021). Warszawa: Związek Przedsiębiorców i Pracodawców. https://zpp.net.pl/wp-content/uploads/2021/01/25.01. 2021-Business-Paper-Podsumowanie-lockdownu-w-Polsce.pdf

Radlińska, K. M. (2021). Pandemia COVID-19. Implikacje dla polskiego rynku pracy. Zeszyty Naukowe Wydziału Nauk Ekonomicznych, 1(24), 113-126. https://ezeszyty.wne.tu.koszalin.pl/index.php/zeszyty/article/view/161

Scarlett, S. (2020). Lockdown was a waste of time and could kill more than it saved, claims Nobel laureate scientist at Stanford University. Mail Online, May 24. https://www.dailymail.co.uk/news/article-8351649/Lockdown-wa ste-time-kill-saved-claims-Nobel-laureate.html

Smith, A. (1976). An Inquiry into the Nature and Causes of the Wealth of Nations (Original work published in 1776). Indianapolis: Liberty Press.

Smith, A. (1989). Teoria uczuć moralnych (Original work published in 1759) (D. Petsch, Trans.). Warszawa: Państwowe Wydawnictwo Naukowe.

Statystyki koronawirus. (2021). Medicover, August 9. https://www.medicover.pl/ koronawirus/statystyki/ 
Szredzińska, R. \& Włodarczyk, J. (2021). Doświadczenia krzywdzenia oraz dobrostan psychiczny polskich nastolatków w pierwszym okresie pandemii. Dziecko Krzywdzone. Teoria, badania, praktyka, 20(2), 38-62.

The COVID decade: Understanding the long-term societal impacts of COVID-19. (2021). London: The British Academy. https://doi.org/10.5871/bac19stf/ 9780856726583.001

Unton, A. (2021). Walka z pandemia na kredyt. Tyle kosztuje w przeliczeniu na Polaka. Money.pl, 6 kwietnia. https:/www.money.pl/gospodarka/walka-zpandemia-na-kredyt-tyle-kosztuje-w-przeliczeniu-na-polaka-6624740634229 280a.html

Vrain, E., Ryan, L. \& Grossetti, M. (2020). Lockdown 'funnelling': how the pandemic has changed our relationships. The Conversation, July 3. https://the conversation.com/lockdown-funnelling-how-the-pandemic-has-changed-ourrelationships-141831

Zabieglik, S. (2006). Etyka życia gospodarczego w twórczości Adama Smitha. Annales. Etyka w Życiu Gospodarczym, 9(1), 115-124. 